\title{
Predation by Epidendrium billeeanum on Tubastrea coccinea: use of the denuded skeleton for laying eggs
}
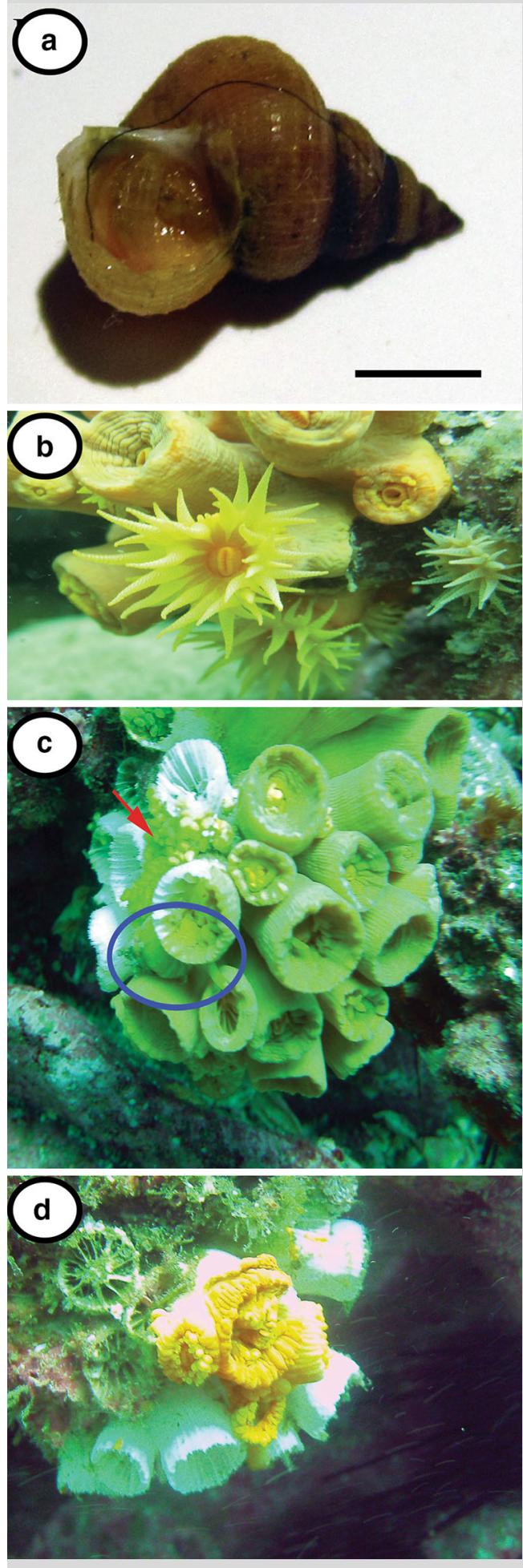

Epidendrium billeeanum (DuShane \& Bratcher, 1965) is a gastropod snail in the family Epitoniidae associated with scleractinean corals and characterized by fragile shells that are usually damaged during the snail's life (Gittenberger and Gittenberger 2005). The snail (Fig. 1a) feeds on the orange cup coral Tubastrea coccinea (Fig. 1b) in the tropical eastern Pacific (TEP). During August 2015 we surveyed the reefs Punta Clavo $\left(11^{\circ} 06.57^{\prime} \mathrm{N}, 85^{\circ} 46.828^{\prime} \mathrm{W}\right)$, Paloma Sur $\left(11^{\circ} 11.347^{\prime} \mathrm{N}, 85^{\circ} 50.359^{\prime} \mathrm{W}\right)$, Marsella $\left(11^{\circ} 16.895^{\prime} \mathrm{N}\right.$, $\left.85^{\circ} 54.399^{\prime} \mathrm{W}\right)$, Gigante $\left(11^{\circ} 10.44^{\prime} \mathrm{N}, 86^{\circ} 0.036^{\prime} \mathrm{W}\right)$ and Mahaual $\left(11^{\circ} 17.706^{\prime} \mathrm{N}, 85^{\circ} 55.275^{\prime} \mathrm{W}\right)$ along the Pacific coast of Nicaragua and we recorded acute tissue loss of $T$. coccinea. Tissue loss was always in association with the presence of the snail which is camouflaged in the polyps of the coral by its yellow coloration (Fig. 1c). The recently denuded coral skeleton was covered with the eggs of the snail which are also yellow and could be confused with the tentacles of the coral (Fig. 1d). Tubastrea tissue loss was seen on reefs from 3 to $11 \mathrm{~m}$ depth in waters of $28{ }^{\circ} \mathrm{C}$. Densities of snails varied between one and three animals per colony. Predation on corals by gastropods is common in the TEP: Jenneria pustulata preys on Porites panamensis (PazGarcía et al. 2012) and Pocillopora species (Rodríguez-Villalobos et al. 2014). This is the first report of predation on T. coccinea in the Pacific of Nicaragua. Permanent monitoring is needed to obtain information on the dynamics of this predation and the subsequent recovery of corals.

Acknowledgments Research was funded by Paso Pacífico Organization-Proyecto ELLAS (ATN/ME-13732NI).

\section{References}

Gittenberger A, Gittenberger E (2005) A hitherto unnoticed adaptive radiation: epitoniid species (Gastropoda: Epitoniidae) associated with corals (Scleractinia). Contrib Zool 74:125-203

Paz-García DA, Aldana-Moreno A, Cabral-Tena RA, Balart EF (2012) High predation by the corallivore sea snail Jenneria pustulata in a high-latitude reef in the Gulf of California. Mar Biodivers Rec 5:e94

Rodríguez-Villalobos JC, Rocha-Olivares A, Work TM, Calderon-Aguilera LE, CáceresMartínez JA (2014) Gross and microscopic pathology of lesions in Pocillopora spp. from the subtropical eastern Pacific. J Invertebr Pathol 120:9-17

J. C. Rodríguez-Villalobos (iD ( $\triangle)$

Ecología Marina, CICESE, Ensenada, BC 22860, Mexico e-mail: jennica13@hotmail.com

A. Ayala-Bocos

Ecosistemas y Conservación: Proazul Terrestre A. C., La Paz, BCS 23080, Mexico

L. Hernández

Laboratorio de Sistemas Arrecifales, Universidad Autónoma de Baja California Sur, La Paz, BCS 23080, Mexico

Fig. 1 a The predator snail Epidendrium billeeanum (scale bar $3 \mathrm{~mm}$ ), b a healthy colony of Tubastrea coccinea, $\mathbf{c}$ a snail behind the polyps (circle) and mass of eggs (arrow), $\mathbf{d}$ eggs on an almost dead colony

Received: 31 August 2015/Accepted: 13 November 2015/Published online: 21 November 2015

Coral Reefs (2016) 35:271

(C) Springer-Verlag Berlin Heidelberg 2015 DOI $10.1007 / \mathrm{s} 00338-015-1379-7$ 